\title{
不活性電極上への銀の電解析出を利用した電気化学素子の動作の 基礎的研究
}

\author{
山川 烈*, 松 尾 正 之* \\ Basic Properties of an Electrochemical Device Utilizing \\ Electrodeposition of Silver on an Inert Electrode
}

Takeshi YAMAKAWA* and Tadayuki MATSUO*

This paper describes the electrical characteristics of an electrochemical cell, termed an "electrodeposition diode", which utilizes electrodeposition on an inert electrode of silver from an electrolytic solution containing the metalic ions. The static characteristics of the diode at low current density shows a memory-switching characteristics like that of an amorphous semiconductor. On the other hand, its transient terminal voltage by the galvanostatic method shows a peak wave form. The peak value $V_{p}$ and the required time $t_{\mathrm{p}}$ to the peak value are dependent on the step current density $I$, and the product $t_{\mathrm{p}} \cdot I$ is constant. This transient phenomenon occurs only for the cathodic step current.

Mathematical analysis and experimental results show that the electrodeposition diode is a variable capacitor whose value is controlled by the amount of pre-deposited silver on the inert cathode. This suggests that the electrodeposition diode may be used as a memory device. The distinctive features of this diode as a memory device are electrical alterability, nondestructive readout, nonvolatility, low power dissipation, low cost, and easy fabrication.

1 緒論 (Introduction)

本研究は不活性電極表面へ異種金属が析出するときの -電気的特性を調心，電子工学への応用の可能性を知るこ とを目的としたものである。はじめに白金電極上への銀 の析出現象の電気的特性を調べるために，1 規定硝酸銀 溶液と白金電極加らなる簡単なダイオードを構成し，数 $\mu \mathrm{A} / \mathrm{cm}^{2}$ 以下の電流密度については静特性を，また，そ れ以上の電流密度について注定常值を得るのが困難なの で過渡特性を測定する。つぎに，この現象を記憶素子に 泣用寸ることを考え，その動作特性について述べる。

\section{2 実験と考察 (Experimental and Discussion)}

\section{1 金属析出タイオードの試作} 金属析出現象の電気的特性を調べるために, Fig. 1(a)

”東比人兴工学部 (优台市荒巻学青菜) Department of Electronics, Faculty of Engineering, Tohoku University (Aoba, Aramaki, Sendai)

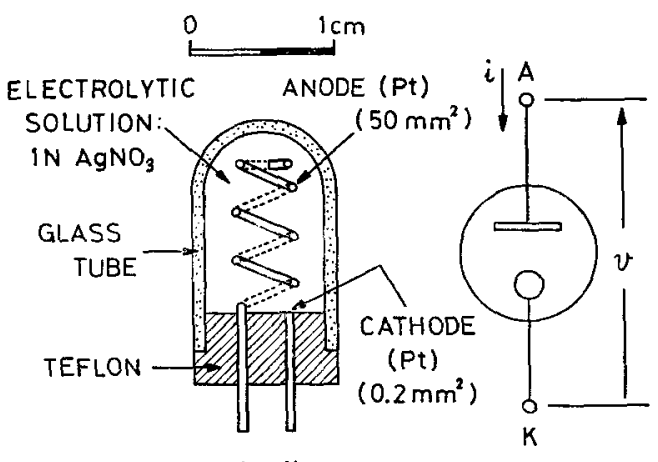

A $K$

(a)

(b)

Fig. 1. Structure (a) and symbol (b) of the electrodeposition diode

に示す構造のダイオードを試作した。以下ではこれを金 属析出ダイオード(Electrodeposition Diode) と呼ぶこと にする，また金属を析出させる電極をカソード(K)，対 
極をアノード(A)とし，アノードにおける電極反応を無 視できるようにするためにアノードとカソードの電極面 積を極端に非対称にする．本実験ではアノードおよび力 ソードの不活性電極として $0.5 \mathrm{~mm}^{\phi}$ の白金線を用い電 解液に接する表面積がそれぞれ約 $50 \mathrm{~mm}^{2}$ および約 0.2 $\mathrm{mm}^{2}$ となるようにした。

なお，これらの電極は次の手順で前処理を行った。 (i) エメリーペーパー (0/8) で研摩, (ii) 洗剂で洗浄し た後水洗い，(iii）アセトンで洗浄した後水洗い，(iv） 熱濃硝酸中に 5 分間浸した後水洗い，(v)熱濃塩酸中に 5 分閒浸した後水洗い, (vi) 蒸留水で洗浄. このように して前処理したアノードとカソードを電解液( 1 規定硝 酸銀溶液) 中に浸して Fig. 1 (a) に示すようにガラス およびテフロンで密封した。

この金属析出ダイオードの記号は Fig. 1 (b) のよう に表わすことにする.ここで電流が電解液中をアノード からカソードに向って流れる場合を順方间 $(i>0)$ ，之の 反対の向きに流孔る場合を逆少向 $(i<0)$ と呼ぶことに する。

\section{2 端子電圧亡電流の関係式}

電極界面を通って電流が流れると，そこで電荷移動反 応(1)が生じ，吸着原子 $\mathrm{Ag}$ (ad-atom) が生成または消 費される。この吸着原子は結晶化反応（2）により結晶格 子に組み込まれるか，あるい洁結晶格子から切り離され る.

$$
\mathrm{Ag}^{+}+e^{-\rightleftarrows \mathrm{Ag}} \text { (ad-atom) }
$$

(電荷移動反応)

$\mathrm{Ag}\left(\right.$ ad-atom) $\underset{v_{a}}{\stackrel{v_{l}}{\longrightarrow}} \mathrm{Ag}$ (lattice)

$$
\text { (結晶化反灾) }
$$

ここで る. 結晶化過電圧 $\eta$ は近似的に(3)式で表わされ”, 金属 析出ダイオードに電流密度 $i\left(\mathrm{~A} / \mathrm{cm}^{2}\right)$ の電流を流したと
きの端子電压 $v$ は, 電荷移動反応(1)がすみやかに進行 すると考えると(4)式で表わすことができる。

$$
\begin{aligned}
& \eta=\frac{R T}{F} \ln \frac{C_{\mathrm{ad}}{ }^{0}}{C_{\mathrm{ad}}} \\
& v=\frac{R T}{F} \ln \frac{C_{\mathrm{ad}}}{C_{\mathrm{ad}}{ }^{0}}+r_{\mathrm{s}} \cdot i
\end{aligned}
$$

$r_{\mathrm{s}}$ は溶液抵抗， $C_{\mathrm{ad}}{ }^{0}, C_{\mathrm{ad}}$ はそれぞれ平衡状態および 電流が流れているときのカソード表面の吸着原子濃度で ある. (4)式は金属析出ダイオードに $i$ なる電流を流し たときの端子電圧が，カソード表面における吸着原子濃 度 $C_{\mathrm{ad}}$ 上溶液抵抗 $r_{\mathrm{s}}$ によって規定されることを示して いる。

\section{3 静特性}

定常値の得やすい低電流レベルでの静特性を調べる. まずカソードに銀が析出していない状態で，しかも電流、 密度 $I$ が数百 $\mathrm{nA} / \mathrm{cm}^{2}$ を越えない範囲で電圧一電流特

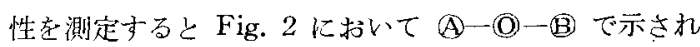
るような高抵抗状態 $\left(\approx 80 \mathrm{~K} \Omega \cdot \mathrm{cm}^{2}\right)$ を示し, この領域. ではヒステリシスを生じない。これは電荷移動反応 (1) によってカソード表面に生成される吸着原子の量と, 沖 合一拡散する吸着原子の量がつりあって, 結晶化の生じ ない，ある濃度に抢らつくためであると思われる。

次に電流レベルを上げると，生成される吸着原子の量 が挔散によって減少する量よりも優勢になり，カソード 表面の吸着原子漂度が増大して不安定な過飽和状態とな る.そして銀の結晶核が形成されるとそれを中心として 集中的に銀の結晶化が起り，吸着原子濃度 $C_{\mathrm{ad}}$ が減少 し(4)式によって端子電圧 vが降下すか. Fig. 2 にお いて (3) $\rightarrow$ C 9 過程がこのことを示している.カソード 表面に結晶核が形成された後は, 結晶核が存在しない場 合に比べて結晶化が容易になり，電流レベルを上げても 吸着原子賑度が高くなりにくいため端子電圧りは上昇し にくい．Fig. 2 の(C)-(D)の低抵抗状態がそれである. 一度(から(C)移行した後は電流レベルを上げても下げ
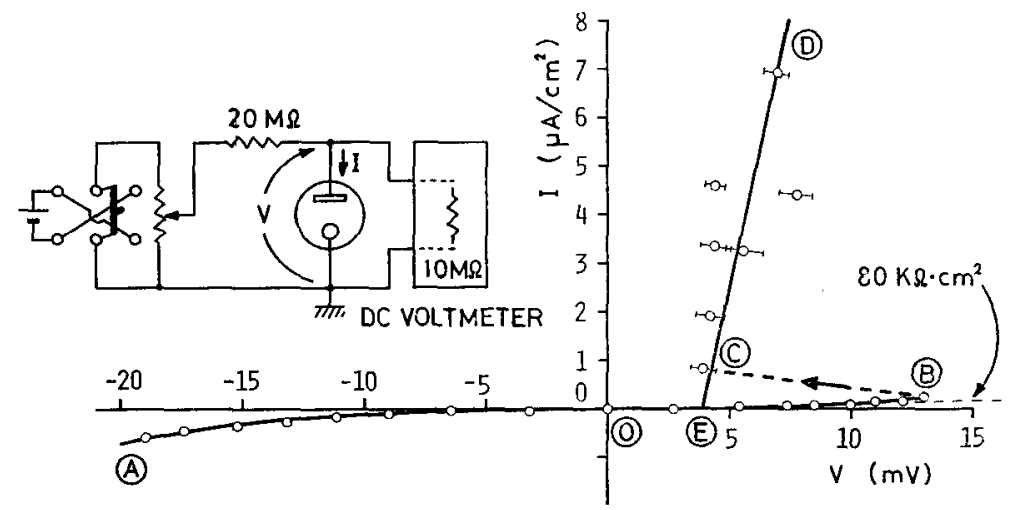

Fig. 2 Static characteristics of the electrodeposition diode $T=20^{\circ} \mathrm{C}$, (A) $\mathrm{Pt} \mid 1 \mathrm{NAgNO} / \mathrm{Pt}$ (1) 
てもこの低抵抗状態は変わらない（代一(C)一(D)の状態).

一方，低抵抗状態になった金属析出ダイオードに逆方 向に（すなわちカソードからアノードへ）電流を流し， カソード表面に析出していた銀を電気的にすべて溶解し

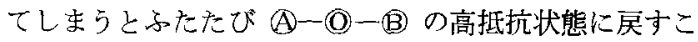
とができる。

\section{4 過渡特性}

電流レベルが高くなると定常値を得ることが困難にな るため，過渡特性によって金属析出ダイオードの電気的 特性を調ベることにする，電流密度 $I\left(\mathrm{~A} / \mathrm{cm}^{2}\right)$ のステッ プ電流を流したときの端子電圧vの時間変化は, 二重層 容量の効果を無視すると(4) 式より次のようになる.

$$
\frac{d v}{d t}=\frac{R T}{F} \cdot \frac{1}{C_{\mathrm{ad}}} \cdot \frac{d C_{\mathrm{ad}}}{d t}
$$

またステップ電流が流れ始めてから吸着原子の拡散が罡 視できるほど短加い時閒内に拉いては次式が成立する。

$$
\begin{aligned}
& -\frac{d C_{\mathrm{ad}}}{d t}=-\left.\frac{d C_{\mathrm{ad}}}{d t}\right|^{\text {ch }}+\left.\frac{d C_{\mathrm{ad}}}{d t}\right|^{\mathrm{cr}} \\
& =\frac{I}{F}-v_{l a}
\end{aligned}
$$

ここで $v_{l a}=v_{l}-v_{a}$ はみかけの結晶化速度であり，結晶 核の数, 吸着原子の濃度などの複雑な関数として表わき れる。(5)式と(6)式上り(7)式が得られる。

$$
\frac{d v}{d t}=\frac{R T}{F} \cdot \frac{1}{C_{\mathrm{ad}}} \cdot\left(-\frac{I}{F^{-}}-v^{\prime} z a\right)
$$

まずカソードに核か゚まったく存在しない初期状態で順方 向のステップ霓流 $I$ 流寸と $v_{l a}=0$ 西るから(7)式 上り $d v / d t>0$ となり端子電压は上昇する．しかし $C_{\mathrm{ad}}$ が過飽和濃度に達して核が形成されると $v_{l a}>0$ とな る.さらに結晶化が進み $I / F<v_{l a}$ となると(7)式より $d v / d t<0$ となって端子電圧は降下するので過渡応答に ピークが生ずる. 次に, や注りカソードに核がまったく 存在しない初期状態で逆方向のステップ電流ーI 流す と $v_{l a}=0$ であるから (6)式执よび(7)式より $C_{\mathrm{ad}}$ 泣減 少するだけで $d v / d t$ は負の方向化增大しピークは生し ない.

ステップ電流の電流密度 $I\left(\mathrm{~A} / \mathrm{cm}^{2}\right)$ をパラメータとし て順方向㧍よび逆方向の端子電圧の過渡応答を測定する と Fig. 3 (a)，(b)のようになり上で述べた解析結果を 裹づけている，ピーク值 $V_{\mathrm{p}}$ およびピークに達する時間 $t_{\mathrm{p}}$ は順方向ステップ電流密度 $I$ に依存し, それらの関 倸を Fig. 4 に示す. Fig. 4 から $t_{\mathrm{p}}$ とI の関倸式と して (8) 式が得られる.

$$
t_{\mathrm{p}} \cdot I=q_{\mathrm{p}}=\text { const. }
$$

すなわち端子電圧の過渡応答がピークに達するまでに必 要な単位面積当たりの電気量 $q_{\mathrm{p}}$ 位一定で, 与えられた 金属析出ダイオードの電気的特性を示す一つのパラメー タである.この $q_{\mathrm{p}}$ 汇記憶素子 (後述)として応用する 際に重要なパラメータとなる.

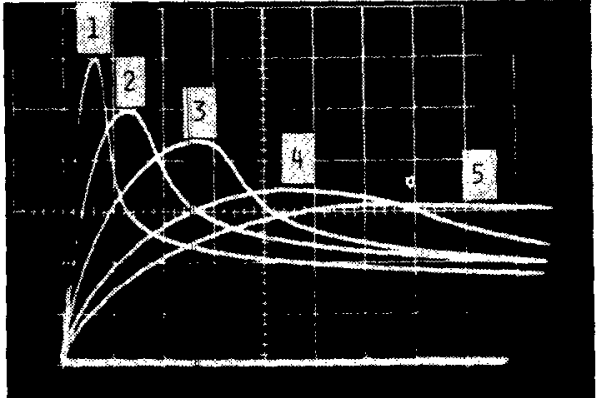

Fig. 3 (a) Typical forward transients (Terminal voltage responses to forward step currents)

$T=25^{\circ} \mathrm{C}, \mathrm{V}: 20 \mathrm{mV} / \mathrm{div} ., \mathrm{H}: 2 \mathrm{msec} / \mathrm{div}$.

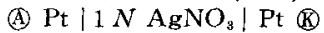

1: $I=10 \mathrm{~mA} / \mathrm{cm}^{2}\left(V_{\mathrm{p}}=120 \mathrm{mV}\right)$

$2: I=5.0 \mathrm{~mA} / \mathrm{cm}^{2}\left(V_{\mathrm{p}}=100 \mathrm{mV}\right)$

$3: I=2.5 \mathrm{~mA} / \mathrm{cm}^{2}\left(V_{\mathrm{p}}=88 \mathrm{mV}\right)$

$4: I=1.5 \mathrm{~mA} / \mathrm{cm}^{2}\left(V_{\mathrm{p}}=70 \mathrm{mV}\right)$

$5: I=1.0 \mathrm{~mA} / \mathrm{cm}^{2}\left(V_{\mathrm{p}}=63 \mathrm{mV}\right)$

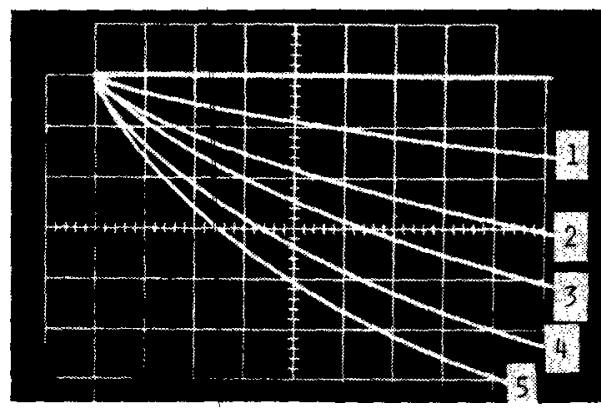

Fig. 3 (b) Typical backward transient: (Terminal voltage resporises to backward step currents)

$T=25^{\circ} \mathrm{C}, \mathrm{V}: 10 \mathrm{mV} / \mathrm{div}, \mathrm{H}: 2 \mathrm{msec} / \mathrm{div}$.

(4) Pt $\left|1 N \mathrm{AgNO}_{8}\right| \mathrm{Pt}(\mathbb{B}$

$1: I=0.1 \mathrm{~mA} / \mathrm{cm}^{2}, \quad 2: I=0.2 \mathrm{~mA} / \mathrm{cm}^{2}$

$3: I=0.3 \mathrm{~mA} / \mathrm{cm}^{2}, \quad 4: I=0.4 \mathrm{~mA} / \mathrm{cm}^{2}$

$5: I=0.5 \mathrm{~mA} / \mathrm{cm}^{2}$

\section{3 記㥽素子としての特㤬 \\ (Menory Characteristics)}

2.4 で述べたよらに金属析出ダイオードにステップ電 流 $I$ を流した場合の端子電圧の過渡応答の立ち上りは $C_{\mathrm{ad}}=\mathrm{C}_{\mathbf{a d}}{ }^{0}(t=0)$ を教虑して一般に(9)式の上らに表わ せる.

$$
\left.\frac{d v}{d t}\right|_{\mathbf{t}=0}=\frac{R T}{F} \cdot \frac{1}{C_{\mathrm{ad}^{0}}^{0}} \cdot\left(-\frac{I}{F}-v_{l a 0}\right)
$$

ここで $v_{\ell a_{0}}$ は $t=0$ に扮けるみかけの結晶化速度であ り，ステップ電流 $I$ を流すときの初期状態で既に定まっ ている.もし，初期状態としてカソードに銀が析出して いなければ v $a_{a 0}=0$ であるが, あらかじめ析出していれ 


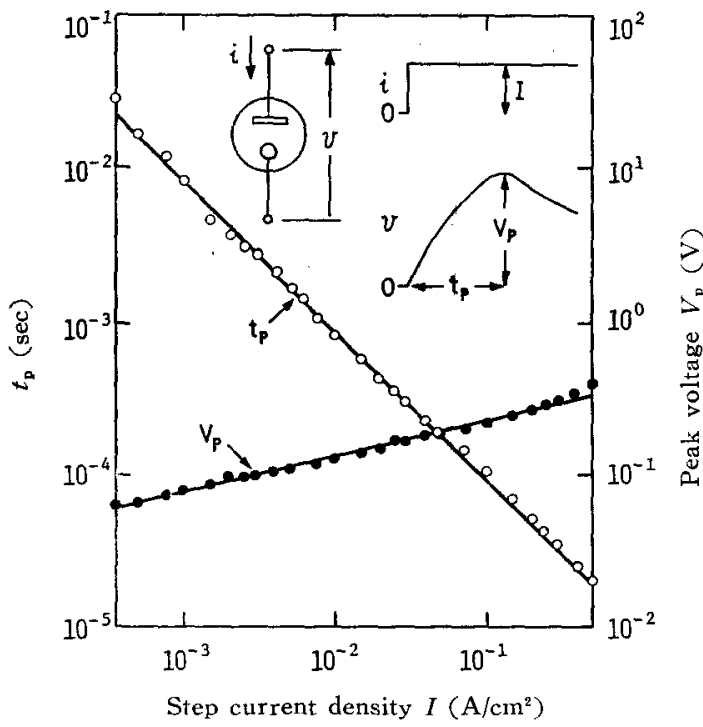

Fig. $4 t_{\mathrm{p}}$ and $V_{\mathrm{p}}$ vs. $I$ plots $T=25^{\circ} \mathrm{C}$, (4) Pt $\left|1 N \mathrm{AgNO}_{s}\right|$ Pt (b)

ば，結晶核がカソード表面に既存するためにステップ電 流を流し始めたときから結晶化反㤁 (2) が右向きに進行 するので $v_{l a 0}>0$ である.よってカソードに銀が析出し ている場合とそらでない場合とではステップ電流に対す る端子電在の過渡応答の立ち上りが異なる。このことか らカソードに銀が既存する場合は“記憶あり”そうでな い場合は“記憶なし”に対応する記憶素子となり得るこ とがわかる。以下では，あらかじめカソードに銀を析出 させることを「書き込み」と称し，書き込まれた情報を 取り出すのにステップ電流を流して過渡店答を観測する ことを「読み出し」と称する。また「書き込み」によっ てカソードに析出した銀を電気的に溶解寸るために逆方 向へ電流を流すことを「消去」と称する。

記憶素子として用いる 金属析出ダイオードの構造は 2.1 で述べたるのと同じであるが、ア!ードおよびカy 一ドとしてはそれぞれ銀と金を用いた。電極の前処理は カソードの場合は 2.1 と同じであるがアノードの場合は 2.1 の (iv) と（v) 除いて行った。 また電解液として は $0.5 \mathrm{~N} \mathrm{HNO}_{3}+0.5 \mathrm{~N} \mathrm{AgNO}_{3}$ を用いた。記憶特性 の測定回路と測定手順を Fig. 5 に示す.ここで「読み 出し」のために流す電流としてはステップの代わりにパ ルスを用いることにするＦig.5（b）に示すように「書 き込み」 $\rightarrow$ 「読み出し」 $\rightarrow$ 「消去」 $\rightarrow$ 「書き込み」 $\rightarrow \cdots \cdots$ の 操作を繰り返し行い, 種々の書き込双パルス振幅 $\left(I_{\mathrm{w}}\right.$

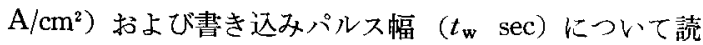
み出し波形（読み出しパルス電流に対する端子電圧の過 渡応答）を観測して書き込为電気量 $Q_{\mathrm{w}}=I_{\mathrm{w}} \cdot t_{\mathrm{w}}$ 上諳 み出し波形の立ち上り $d v /\left.d t\right|_{\mathrm{t}=0}$ の関係を調べる.Fig.6 (a)

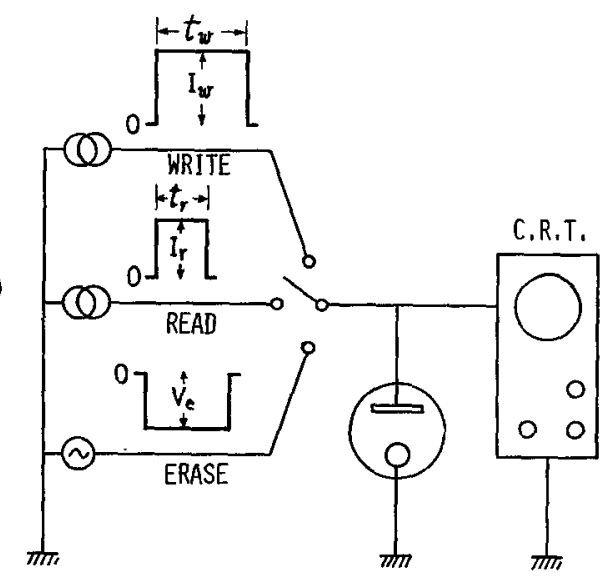

(b)

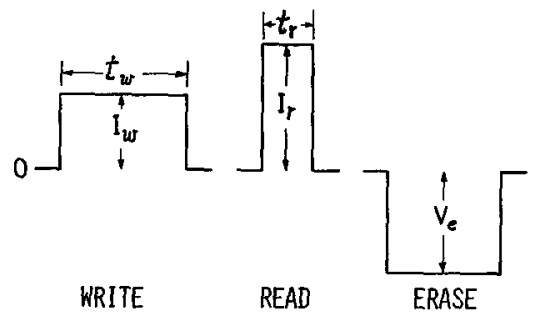

Fig. 5 Memory characteristics measuring circuit (a) and pulse train diagram of WRITEREAD-ERASE cycle (b)

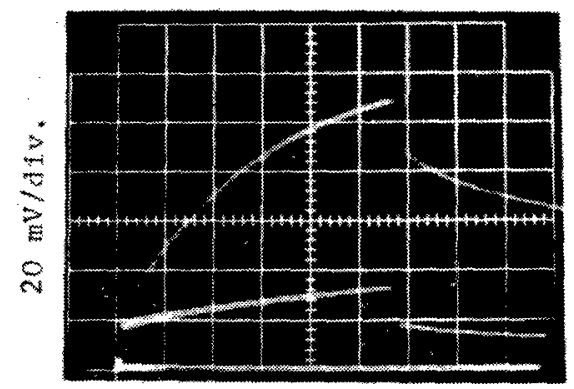

(a)

$10 \mu \mathrm{sec} / \mathrm{div}$,

Fig. 6 Typical READ OUT waveforms (4) $\mathrm{Ag}\left|0.5 \mathrm{~N} \mathrm{AgNO}+40.5 \mathrm{~N} \mathrm{HNO}_{3}\right| \mathrm{Au}$ (B) $T=18.5^{\circ} \mathrm{C}, I_{\mathrm{r}}=50 \mathrm{~mA} / \mathrm{cm}^{2}, t_{\mathrm{r}}=55 \mu \mathrm{sec}$

(a) : $I_{\mathrm{w}}=0 \mathrm{~mA} / \mathrm{cm}^{2}, t_{\mathrm{w}}=0 \mathrm{msec}$

(b) : $I_{\mathrm{w}}=50 \mathrm{~mA} / \mathrm{cm}^{2}, t_{\mathrm{w}}=1160 \mathrm{msec}$

は（a）記憶なし” $\left(Q_{\mathrm{w}}=0 \mathrm{msec} \times 0 \mathrm{~mA} / \mathrm{cm}^{2}\right)$ および (b) “記憶あり” $\left(Q_{\mathrm{w}}=1160 \mathrm{msec} \times 50 \mathrm{~mA} / \mathrm{cm}^{2}\right)$ の場合の読 欢出し波形の例を示寸.また Fig. 7 は書き込み電気量 $Q_{\mathrm{w}}$ と読み出し波形の立ち上り $d v / d t_{\mathrm{t}=0}$ の関係を示す。 Fig. 7 では $t_{\mathrm{r}}=10 \mu \mathrm{sec}$ の読み出しパルスを用いたが 


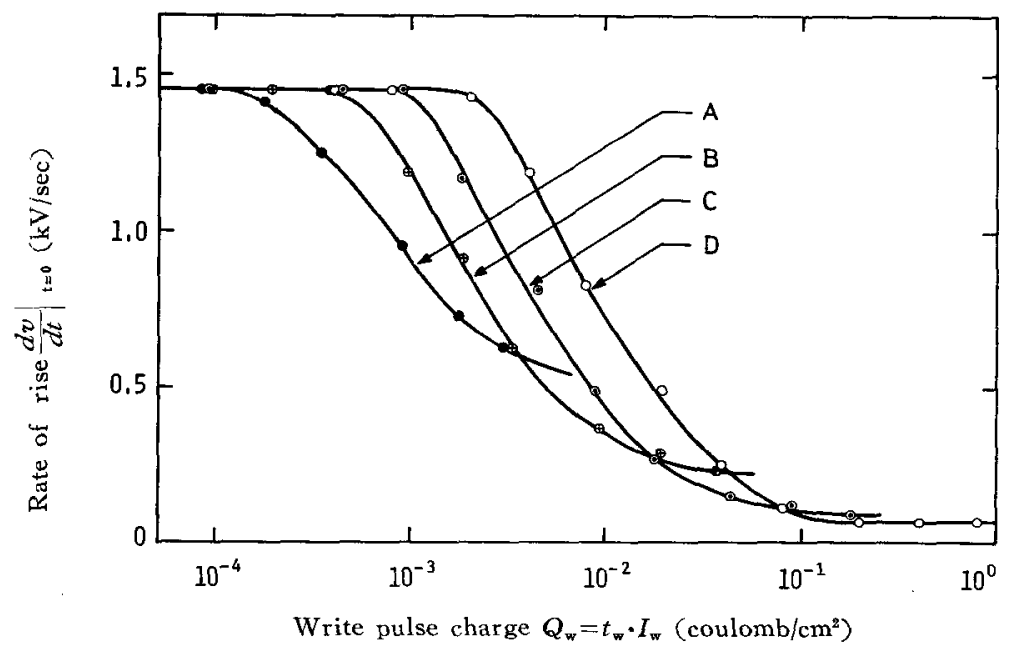

Fig. 7 Rate of rise of readout waveform vs. write pulse charge $\mathrm{A}: t_{\mathrm{w}}=3.5 \mathrm{msec}, \mathrm{B}: t_{\mathrm{w}}=38 \mathrm{msec}, \mathrm{C}: t_{\mathrm{w}}=180 \mathrm{msec}, \mathrm{D}: t_{\mathrm{w}}=800 \mathrm{msec}$ $t_{\mathrm{r}}=10 \mu \mathrm{sec}, I_{\mathrm{r}}=50 \mathrm{~mA} / \mathrm{cm}^{2}, V_{\mathrm{e}}=-100 \mathrm{mV}, T=19^{\circ} \mathrm{C}$ (A) $\mathrm{Ag}\left|0.5 \mathrm{NAgNO}+3+0.5 N \mathrm{HNO}_{3}\right| \mathrm{Au}$ (1)

Fig. 6 では写真撮影のために $\boldsymbol{t}_{\mathbf{r}}=\mathbf{5 5} \mu \mathrm{sec}$ の読み出し パルスを用いた。

Fig. 7 より凄き込みパルス電気量 $Q_{\mathrm{w}}$ が大で西るほ ぞ，読み出し波形の立ち上り $d v /\left.d t\right|_{\mathrm{t}=0}$ が小になり， $Q_{\mathrm{w}}$ がある程度以下の場合注にとんど書き込みがなされ ないことがわかる．また同一電気量で書き込みを行って る書き込みパルス幅 $t_{\mathrm{w}}$ が大なるほど，読み出し波形の 立ち上りは小となる．Fig. 7 は，金属析出ダイオードが 書き込子電気量に上って等価的な容量が変化する可变容 量ダイオードであることを示している，本実験では電流 性パルスによる書き込みについて論じたが，電圧性パル スによる書き込みも可能であり，場合によって使いわけ ることができる。

読み出しパルス幅 $t_{\mathrm{r}}$ が 2.4 で述べた $t_{\mathrm{p}}$ よりも大と すると“記憶なし”の状態を読み出す場合, 読み出しパ ルスによって「書き込み」がなされてしまうために破壊 読み出しとなる.よって連続的な非破壊読み出しを可能 にするために $t_{\mathrm{r}}$ は $t_{\mathrm{p}}$ よりも十分小さくなければなら ないから(10)式を满足しなければならない。

$$
t_{\mathrm{r}} \ll t_{\mathrm{p}}
$$

よって (8) 式扔よび (10) 式より $I$ を $I_{\mathrm{r}}$ とおきかえて (11)式党得る.

$$
t_{\mathrm{r}} \cdot I_{\mathrm{r}}\left\langle\left\langle q_{\mathrm{p}}=\right.\right.\text { const. }
$$

ただし $q_{\mathrm{p}}$ は与艺られた金属析出ダイオードに固有の定 数で $t_{\mathrm{p}}-I$ 特性から求めることができる. 非破壊読み出 しを可能にするに法，読み出しパルス $\left(t_{\mathrm{r}}, I_{\mathrm{r}}\right)$ は (11) 式を满足しなければならない，筆者らは交流（正弦波） による非破壊読み出し法も可能であることを確かめた。

以上のこと䣄の析出を用いた金属析出ダイオードに
ついてであるが，銅の析出を用いた金属析出ダイオード についても同樣の結果を得た。なお Fig. 7 で $d v /\left.d t\right|_{\mathrm{t}=0}$ $-Q_{\mathrm{w}}$ 特性が $t_{\mathrm{w}}$ によって異なった曲線走示す原因につ いては, まだ明らかでない。

記憶素子としての金属析出ダイオードは，(1) 非破壊 読み出しが可能，(2) 電気的書き換えが可能，(3) 不揮 発性メモり(電源が切れても記憶法保存される)，(4)消 費電力が少い(試作ダイオードで $2 \mu \mathrm{W}$ 以下)，(5) $\mu \mathrm{sec}$ 程度の速さでの「読み出し」が可能，(6) 製作が容易， （7）低廉，などの多くの特長を有し，将来の态用が期待 される素子であると思われる。

\section{4 結 論 (Conclusions)}

銀の不活性電極上一の電解析出を用いた金属析出ダイ オードの静特性および動特性から次の結諭が得られた。

(1) 銀がカソードに存在する場合上存在しない場合上 では異なる電圧一電流特性が得られた。

(2) 数百 $\mathrm{nA} / \mathrm{cm}^{2}$ 以上の順方向ステップ電流に対する 端子電圧の過渡応答にはピークが生ずるが，逆方向のそ れにはピークは生じない。

(3) 順方向ステップ電流化対する端子電圧の過渡态答 がピークに達するまでに必要な電気量 $q_{\mathrm{p}}$ は与えられた 金属析出ダイオードについて固有の定数である.

また金属析出ダイオードの応用に関する実験から，金 属析出ダイオードは，書き込み電気量によって容量が変 化する可変容量ダイオードであり，非破壊読み出しが可 能な不揮発性メモリとして応用できることが明らかとな った。 


\section{記一号 表}

$C_{\mathrm{ad}}{ }^{0}, C_{\mathrm{ad}}$; 平衡状態おるび電流が流れているときの力 ソード表面の吸着原子嶩度

$\left.\frac{d C_{\text {ad }}}{d t}\right|^{\text {ch }},\left.\frac{d C_{\text {ad }}}{d t}\right|^{\text {cr }}$; 電荷移動反応および結晶化反応 による $C_{\mathrm{ad}}$ の時間変化

$i$; 金属析出ダイオードを流れる電流

$I$ ；ステップ電流または直流電流の電流密度

$I_{\mathrm{r}}$; 読み出しパルス電流の振幅

$I_{\mathrm{w}}$; 畫き込みパルス電流の振幅

$q_{\mathrm{p}}$; ステップ電流による端子電圧の過渡灾答がピークに

達するまでに必要な単位面積当たりの電気量 $\left(=t_{\mathrm{p}}\right.$ - I)

$Q_{\mathrm{w}}$; 書き込みパルス電気量 $\left(=t_{\mathrm{w}} \cdot I_{\mathrm{w}}\right)$

$r_{\mathrm{s}}$; 溶液抵抗

$t_{\mathrm{p}}$ ；ステップ電流による端子電圧の過渡応答がピークに 達する時間

$t_{\mathrm{r}}$; 読み出しパルス電流のパルス幅 $t_{\mathrm{w}}$ ；書き込みパルス電流のパルス幅

$v ;$ 金属析出ダイオードの端子電圧

$v_{a}$ ；吸着原子生成速度

$v_{l} ;$ 結晶化速度

$v_{l a} ;$ みかけの結晶化速度 $\left(=v_{l}-v_{a}\right)$

$v_{l a 0} ; t=0$ におけるみか子技晶化速度

$V$; 金属析出ダイオードの端子電圧の直流值

$V_{\mathrm{e}}$;消去パルス電圧の振幅

$V_{\mathrm{p}}$; ステップ電流による端子電圧の過渡応答のピーク值

$\eta ;$ 結晶化過電压

本研究にあたり有益なで討論をいただいた東北大学工学部応 用化学科・外帠忍教授，東北大学工学部 電子工学科・柴田幸男 教授, 東北大学電気通信研究所・西沢潤一教授に厚く謝意を表 します。

$<1453>\quad$ (Received June 24, 1974)

文献

1) H. Gerischer, Z. Elektrochem. 67, 256 (1958).

\title{
Anodic Processes of Oxidation of Chromium(III) Sulfate in Aqueous Sulfuric Acid Solution
}

\author{
Ju-Seong LEE* and Taro SEKINE*
}

\begin{abstract}
The electrolytic oxidation of chromium(III) sulfate in sulfuric acid solution at lead dioxide and platinum anodes under various conditions of anode potential, acid concentration and temperature has been studied, and the formation of peroxydisulfuric acid affecting the oxidation of chromium(III) ion has been also discussed.

The current efficiency for the dichromate formation on a lead dioxide anode increases with decreases in the acid concentration at low potentials, while it is almost independent of the operating temperature under the constant concentration and anode potential.

It may be supposed that the oxidation of chromium(II) sulfate on a lead dioxide anode is not a simple electrochemical process, but a catalytic reaction of chromium(III) ion on the anode surface.

Furthermore, the anodic oxidation of chromium(III) sulfate is closely related to the reaction of chromium(III) ion with peroxydisulfuric acid, which will be formed at the anode.

On the other hand, a small amount of dichromate was detected by electrolysis of concentrated sulfuric acid solution with a platinum anode at the potential of formation of peroxydisulfuric acid.
\end{abstract}

\footnotetext{
* 東京工業大学工学部 (東京都目黑区大网山2-12-1) Department of Electrochemistry, Tokyo Institute of Technology (2-12-1, Ookayama, Meguro-ku, Tokyo)
} 